\title{
PROKRASTINASI AKADEMIK DALAM PERSPEKTIF ISLAM
}

\author{
Harmalis \\ Jurusan Bimbingan dan Konseling Pendidikan Islam, LAIN Kerinci \\ e-mail: harmalis@iainkerinci.ac.id
}

\begin{abstract}
Abstrak. Generasi muda memiliki peranan penting dalam meningkatkan dan membangun pendidikan Indonesia. Mahasiswa merupakan salah satu unsur dari generasi muda yang dapat mengembangkan dan meningkatkan sumber daya manusia. Dalam kegiatan belajar dan mengajar, pengerjaan tugas kuliah yang diberikan oleh dosen merupakan suatu rutinitas yang mesti dilalui dan dilakukan oleh setiap mahasiswa, namun sering kali kita melihat dan mendengar bahwa sebagian mahasiswa terlambat dalam mengerjakan tugas. Keterlambatan dalam mengerjakan tugas merupakan salah satu bentuk perilaku prokrastinasi akademik (perilaku menunda pekerjaan). Dalam perspektif Islam para penganutnya dianjurkan untuk menghidari atau menjauhkan diri dari perilaku prokrastinasi akademik. Perilaku prokrastinasi akademik bisa berdampak buruk dalam pengembangan dan peningkatan kapasitas serta potensi diri umat, oleh karena itu perilaku prokrastinasi akademik sangat dilarang dalam kehidupan kaum muslimin, hal ini didukung dengan banyak dalil-dalil hadits dan Al Qur'an yang melarang dan mencela manusia yang menunda suatu pekerjaan. Tujuan penulisan ini adalah mendeskripsikan pentingnya menghindarkan diri dari perilaku prokrastinasi akademik dalam kehidupan individu dan hal-hal yang berkaitan dengan pandangan Islam terhadap perilaku prokrastinasi akademik. Metode dalam penulisan ini adalah studi pustaka yakni dengan memaparkan dan menganalisis beberapa teori dan pandangan Islam tentang prokrastinasi akademik.
\end{abstract}

Kata kunci: prokrastinasi akademik, perspektif Islam

\begin{abstract}
The younger generation has an important role in improving and developing Indonesian education. Students are one element of the younger generation who can develop and improve human resources. In teaching and learning activities, the coursework given by the lecturer is a routine that must be passed and carried out by every student, but we often see and hear that some students are late in doing their assignments. Delay in doing assignments is a form of academic procrastination behavior (behavior of delaying work.). In the Islamic perspective, its adherents are encouraged to avoid or distance themselves from academic procrastination. The behavior of academic procrastination can have a negative impact on the development and improvement of the capacity and potential of the people, therefore the behavior of academic procrastination is strictly probibited in the lives of Muslims, this is supported by many evidences of the hadith and the Qur'an that probibit and denounce humans who procrastinate. a job. The purpose of this paper is to describe the importance of avoiding academic procrastination behavior in individual life and matters relating to the Islamic view of academic procrastination behavior. The method in this writing is a literature study by describing and analyzing several Islamic theories and views on academic procrastination.
\end{abstract}

Keywords: academic procrastination, Islamic perspective 


\section{PENDAHULUAN}

Generasi muda memiliki peranan penting dalam meningkatkan dan membangun pendidikan Indonesia, hal ini dapat dilihat dari setiap aktivitas generasi muda dalam mengembangkan dan meningkatkan SDMnya. Mahasiswa merupakan salah satu unsur dari generasi muda yang dapat mengembangkan dan meningkatkan sumber daya manusia (SDM). Dalam kegiatan belajar dan mengajar, pengerjaan tugas kuliah yang diberikan oleh dosen merupakan suatu rutinitas yang mesti dilalui dan dilakukan oleh setiap mahasiswa, namun sering kali kita melihat dan mendengar bahwa sebagian mahasiswa terlambat dalam mengerjakan tugas. keterlambatan dalam mengerjakan tugas merupakan salah satu bentuk perilaku menunda. Perilaku menunda bisa berdampak buruk dalam pengembangan dan peningkatan kapasitas serta potensi diri mahasiswa, oleh karena itu perilaku menunda sangat tidak dianjurkan dalam kehidupan dewasa ini.

Dalam perspektif Islam para penganutnya sangat dilarang menunda-nunda suatu pekerjaan yang semestinya bisa dilakukan saat itu, hal ini sejalan dengan hadis Rasulullah SAW, yang artinya "Gunakanlah lima perkara sebelum datang lima perkara lainnya; gunakanlah masa mudamu sebelum masa tuamu, masa hidupmu sebelum datang kematianmu, waktu luangmu sebelum waktu sibukmu, waktu sehatmu sebelum waktu sakitmu, dan waktu kaya sebelum waktu miskinmu." (HR Hakim).

Hadis Rasullullah SAW di atas mengandung pesan kepada umatnya agar tidak menunda pekerjaan. Karena menunda pekerjaan merupakan awal dari timbulnya permasalahan. Apalagi, jika pekerjaan itu merupakan suatu kebaikan atau pekerjaan yang sangat penting. Dalam hadis lain, Rasulullah SAW bersabda,yang artinya "Bersegeralah kamu sekalian melakukan amal-amal yang shalih, karena akan terjadi suatu bencana yang menyerupai malam yang gelap gulita, di mana ada seseorang pada waktu pagi ia beriman tetapi pada waktu sore ia kafir, pada waktu sore ia beriman tetapi pada waktu pagi ia kafir; ia rela menukar agamanya dengan satu kesenangan dunia." (HR Muslim).

Berdasarkan penjelasan diatas dapat dipahami ada beberapa alasan yang menyebabkan dilarangnya menunda pekerjaan. Pertama, kita tidak dapat menjamin untuk hidup pada esok hari. Kedua, tidak ada jaminan esok kita masih diberi nikmat kesehatan, memiliki waktu luang seperti hari ini. Ketiga, menunda pekerjaan yang baik menyebabkan seseorang terbiasa melakukannya, sehingga kemudian menjadi suatu kebiasaan buruk yang sulit dihilangkan. Waktu berjalan sesuai dengan sunatullah. Detik menjadi menit, menit menjadi jam, dan jam menjadi hari, begitu seterusnya. Siang dan malam pun datang silih berganti. Allah SWT berfirman, "Dan Dialah yang menjadikan malam dan siang silih berganti bagi orang yang ingin mengambil pelajaran atau orang yang ingin bersyukur." (QS 25:62). 
Perilaku menunda pekerjaan ini merupakan perilaku tercela karena ia menyia-nyiakan nikmat waktu yang telah diberikan oleh sang pemilik waktu Allah SWT, seperti dalam HR Bukhari, Rassulullah bersabda: "dua nikmat yang sering dilupakan oleh manusia adalah kesehatan dan waktu luang". Menunda pekerjaan dikenal dengan istilah prokrastinasi. Hal ini sejalan dengan pernyataan Steel (2007) yang mengatakan prokrastinasi adalah menunda dengan sengaja kegiatan yang diinginkan walaupun individu mengetahui bahwa perilaku penundaanya tersebut dapat menghasilkan dampak buruk. Brown dan Holzman (Dalam Soetjipto : 1997) mengatakan bahwa Prokrastinasi merupakan suatu kecenderungan menunda-nunda penyelesaian suatu tugas atau pekerjaan. Dapat dipahami bahwa prokrastinasi adalah suatu bentuk perilaku yang dengan sengaja menunda-nunda menyelesaikan tugas atau pekerjaan tertentu.

Peterson (dalam Rizvi : 1998) mengatakan bahwa seseorang dapat melakukan prokrastinasi hanya pada hal-hal tertentu saja atau pada semua hal. Jenis-jenis tugas yang sering ditunda oleh prokrastinator adalah tugas pembuatan keputusan, tugas rumah rangga, tugas aktivitas akademik, pekerjaan kantor, dan lainnya. Menurut Ferrari (1995) prokrastinasi terbagi menjadi dua jenis yaitu (1) Functional Procrastination, yaitu penundaan mengerjakan tugas yang bertujuan untuk memperoleh informasi yang lebih lengkap dan akurat ; (2) Disfunction Procrastination, yaitu penundaan yang tidak bertujuan, berakibat jelek, dan bermasalah. Ghufron (2010) mengatakan prokrastinsi akademik dan non akademik sering menjadi istilah yang digunakan oleh para ahli untuk membagi jenis-jenis tugas yang ditunda oleh prokrastinator, seperti tugas pembuatan keputusan, tugas rumah rangga, tugas aktivitas akademik, dan pekerjaan kantor.

Ferrari (1995) mengatakan Prokrastinasi akademik adalah jenis penundaan yang dilakukan pada jenis tugas formal yang berhubungan dengan akademik, seperti tugas sekolah, kuliah, dan kursus. Prokrastinasi non akademik adalah penundaan yang dilakukan pada jenis tugas non formal atau tugas yang berhubungan dengan kehidupan sehari-hari, seperti tugas rumah tangga, tugas sosial, tugas kantor dan sebagainya. Dapat dipahami prokrastinasi akademik merupakan suatu kecenderungan penundaan yang dilakukan pada tugas formal seperti tugas kuliah dan tugas sekolah yang berhubungan dengan akademik.

Fenomena prokrastinasi akademik banyak ditemui di dalam negeri. hasil penelitian Mayasari, Mustami'ah dan Warni (2010) terdapat sebanyak 75\% mahasiswa Universitas Hang Tuah Surabaya angkatan 2007-2010 melakukan prokrastinasi akademik pada aspek kesenjangan waktu antara rencana kerja dan kinerja aktual serta penelitian Muyana (2018) Hasil yang diperoleh dalam penelitian ini menggambarkan kondisi prokrastinasi akademik mahasiswa pada kategori tinggi $81 \%$. Prokrastinasi akademik yang dialami oleh mahasiswa tersebut terdiri dari 
beberapa aspek antara lain keyakinan akan kemampuan, gangguan perhatian, faktor sosial, manajemen waktu, inisiatif, pribadi, dan kemalasan.

Dari hasil survey penulis di Jurusan BKPI Institut Agama Islam Negeri (IAIN) Kerinci Kota Sungai Penuh, dengan jumlah sampel sebanyak 100 orang mahasiswa, tentang perilaku prokrastinasi akademik, di antaranya yang berhubungan dengan ketepatan waktu dan keterlambatan dalam mengerjakan dan menyelesaikan tugas yang diberikan oleh dosen. Dan diperoleh hasil observasi perilaku prokratinasi mahasiswa Jurusan BKPI Institut Agama Islam Negeri (IAIN) Kerinci adalah 60 mahasiswa memliki perilaku prokrastinasi yang tinggi dan sisanya 40 mahasiswa memiliki perilaku prokrastinasi rendah. Hasil observasi tersebut menunjukkan 40\% mahasiswa yang memiliki perilaku prokrastinasi yang rendah dan sisanya 60\% mahasiswa yang memilki perilaku prokrastinasi yang tinggi. Indikasi perilaku prokrastinasi mahasiswa yang tinggi di antaranya : Mahasiswa menunda untuk memulai dan menyelesaikan tugas, keterlambatan dalam mengerjakan tugas, kesenjangan waktu antara rencana dan kinerja aktual, dan melakukan aktivitas lain yang lebih menyenangkan dari pada mengerjakan tugas. Berdasarkan uraian diatas penulis ingin melakukan pengkajian tentang prokrastinasi akademik dalam perspektif Islam.

\section{PEMBAHASAN}

\section{Pengertian Prokrastinasi Akademik}

Ghufron (2010) mengatakan bahwa Prokrastinasi berasal dari bahasa Latin prokrastination dengan awalan "pro" yang berarti mendorong maju atau bergerak maju dan akhiran "crastinus" keputusan hari esok. Jika digabungkan makna menjadi "menunda sampai hari berikutnya" atau "menangguhkan".

Menurut Steel (2007) Prokrastinasi adalah menunda dengan sengaja kegiatan yang diinginkan walaupun individu mengetahui bahwa perilaku penundaanya tersebut dapat menghasilkan dampak buruk. Brown dan Holzman (Dalam Soetjipto : 1997) mengatakan bahwa Prokrastinasi merupakan suatu kecenderungan menunda-nunda penyelesaian suatu tugas atau pekerjaan. Berdasarkan beberapa pendapat ahli di atas dapat dipahami bahwa prokrastinasi adalah suatu tindakan yang kecenderungan dilakukan dengan sengaja menunda-nunda menyelesaikan tugas atau pekerjaan tertentu.

Solomon dan Rothblum (1984) Mengatakan bahwa prokrastinasi akademik adalah tindakan penundaan yang dilakukan secara sengaja terhadap tugas-tugas dalam lingkup akademik yang berguna untuk mencapai suatu tujuan tertentu. Schouwenburg (dalam Ferrari, 1995) mengatakan bahwa prokrastinasi akademik adalah penundaan dalam melengkapi penilaian akademik, seperti 
mengerjakan pekerjaan rumah (PR), dan Menulis makalah. Berdasarkan beberapa pendapat para ahli di atas dapat dipahami bahwa prokrastinasi akademik adalah tindakan penundaan yang dilakukan secara sengaja terhadap tugas-tugas dalam lingkup akademik seperti mengerjakan pekerjaan rumah (PR), dan Menulis makalah.

\section{Teori-Teori Prokrastinasi Akademik}

Teori Psikodinamika, Freud (dalam Ghufron, 2010) mengatakan seseorang yang dihadapkan tugas yang mengancam ego pada alam bawah sadar akan menimbulkan ketakutan dan kecemasan. Perilaku penundaan atau prokrastinasi merupakan akibat dari penghindaran tugas dan sebagai mekanisme pertahanan diri. Seseorang secara tidak sadar melakukan penundaan untuk menghindari penilaian yang dirasakan akan mengancam keberadaan ego atau harga dirinya. Penganut psikodinamika beranggapan bahwa pengalaman masa kanak-kanak akan mempengaruhi perkembangan proses kognitif seseorang ketika dewasa. Terutama trauma. Orang yang pernah mengalami trauma akan satu tugas tertentu, misalnya gagal menyelesaikan tugas sekolahnya, akan cenderung melakukan prokrastinasi ketika dihadapkan lagi pada suatu tugas yang sama. Dapat dipahami bahwa individu yang pernah mengalami pengalaman kegagalan atau perasaan yang tidak menyenangkan dalam menyelesaikan tugas tertentu, cenderung menunda mengerjakan tugas yang dipersepsikan akan mendatangkan perasaan seperti masa lalu.

Teori Behavioristik, Penganut teori behavioritik beranggapan bahwa perilaku prokrastinasi akan muncul akibat dari proses pembelajaran. Seseorang yang pernah merasakan sukses dalam melakukan tugas sekolah dengan melakukan penundaan, cenderung akan mengulangi lagi perbuatanya. Sukses yang pernah dia rasakan akan dijadikan reward untuk mengulangi perilaku yang sama pada masa yang akan datang. McCown dan Johnson (dalam Ghufron, 2010) mengatakan bahwa adanya objek lain yang memberikan Reward lebih menyenangkan dari pada objek yang diprokrastinasi dapat memunculkan peralaku prokrastinasi. Misalnya seseorang yang merasa main video game lebih menyenangkan dari pada mengerjakan tugas sekolah, mengakibatkan tugas sekolah lebih sering diprokrastinasikan dari pada bermain video game.

Teori Kognitif dan behavioral-kognitif, Ellis dan Knaus (dalam Ghufron, 2010) memberikan penjelasan tentang prkrastinasi dari sudut pandang cognitive-behavioral. Bahwa prokrastinasi terjadi karena adanya keyakinan yang irasional yang dimiliki seseorang. Keyakinan irasional tersebut dapat disebabkan suatu kesalahan dalam mempersepsikan tugas sekolah. Seseorang memandang tugas sebagai sesuatu yang berat dan tidak menyenangkan akan cederung menunda mengerjakannya. 


\section{Faktor-faktor yang Mempengaruhi Prokrastinasi Akademik}

Faktor Internal, faktor internal merupakan faktor-faktor yang terdapat di dalam diri individu yang mempengaruhi prokrastinasi. Meliputi kondisi fisik dan kondisi psikologis dari individu. faktor fisik merupakan keadaan fisik dan kondisi kesehatan, misalnya Fatigue. Seseorang yang mengalami Fatigue akan memiliki kecenderungan yang lebih tinggi untuk melakukan prokrastinasi dari pada yang tidak mengalami Fatigue. Green (dalam Ghufron, 2010) mengatakan salah satu faktor internal (psikologis) yang dapat mempengaruhi prokrastinasi adalah motivasi intrinsik, yakni motivasi yang berasal dari dalam diri individu yang dapat mendorong individu dalam melakukan aktivitas untuk mencapai tujuan tertentu. Misalnya, besarnya motivasi intrinsik seseorang akan mempengaruhi prokrastinasi secara negatif. Semakin tinggi motivasi intrinsik yang dimiliki individu ketika menghadapi tugas, akan semakin rendah kecenderungannya untuk melakukan prokrastinasi. Dan begitu pula sebaliknya semakin rendah motivasi intrinsik, akan semakin tinggi kecenderungannya untuk melakukan prokrastinasi.

Faktor Eksternal, faktor eksternal merupakan faktor-faktor yang terdapat di luar diri individu yang dapat mempengaruhi prokrastinasi. Ghufron (2003) mengatakan salah satu dari faktor eksternal yang dapat mempengaruhi prokrastinasi adalah dukungan sosial seperti dukungan sosial dari orang tua dan dukungan sosial dari teman sebaya. Artinya dukungan sosial dari orangorang yang berada di sekitar individu memiliki hubungan negatif dengan perilaku prokrastinasi individu dalam menghadapi tugasnya.

\section{Ciri-ciri Prokrastinasi Akademik}

Ferrari (dalam Ghufron, 2010) mengatakan bahwa ciri-ciri prokrastinasi adalah sebagai berikut: 1). Penundaan untuk memulai dan menyelesaikan tugasnya, Seorang yang melakukan prokrastinasi tahu bahwa tugas yang dihadapi harus segera diselesaikan. Akan tetapi dia menundanunda untuk memulai mengerjakannya atau menunda-nunda untuk menyelesaikan sampai tuntas jika dia sudah mulai mengerjakan sebelumnya. 2). Keterlamabatan dalam mengerjakan tugas, Orang yang melakukan prokrastinasi memerlukan waktu yang lebih lama daripada waktu yang dibutuhkan pada umumnya dalam mengerjakan suatu tugas. Seorang prokrastinator menghabiskan waktu yang dimilikinya untuk mempersiapkan diri secara berlebihan. Selain itu juga melakukan hal-hal yang tidak dibutuhkan dalam penyelesaian suatu tugas, tanpa memperhitungkan keterbatasan waktu yang dimilikinya. 3). Kesenjangan waktu antara rencana dan kinerja aktual, Seorang prokrastinator mempunyai kesulitan untuk melakukan sesuatu sesuai dengan batas waktu yang telah ditentukan sebelumnya. Seorang prokratinator sering mengalami keterlambatan dalam memenuhi deadline yang telah ditentukan, baik oleh orang lain maupun 
rencana yang telah ditentukan sendiri. 4). Melakukan aktivitas yang lebih menyenangkan, Seorang prokrastinator dengan sengaja tidak melakukannya tugasnya. Akan tetapi, menggunakan waktu yang dia miliki untuk melakukan aktvitas lain yang dipandang lebih menyenangkan dan mendatangkan hiburan.

\section{Prokrastinasi Akademik dalam Perspektif Islam}

Dalam perspektif Islam para penganutnya sangat dilarang untuk melakukan perilaku prokrastinasi akademik (menunda-nunda suatu pekerjaan) yang semestinya bisa dilakukan saat itu, hal ini sejalan dengan hadis Rasulullah SAW, yang artinya "Gunakanlah lima perkara sebelum datang lima perkara lainnya; gunakanlah masa mudamu sebelum masa tuamu, masa hidupmu sebelum datang kematianmu, waktu luangmu sebelum waktu sibukmu, waktu sehatmu sebelum waktu sakitmu, dan waktu kaya sebelum waktu miskinmu." (HR Hakim). Hadis Rasullullah SAW di atas mengandung pesan kepada umatnya agar dapat memanfaatkan waktu sebaik-baiknya dan supaya dapat menjauhkan diri dari perilaku prokrastinasi akademik (menunda pekerjaan). Karena dengan memiliki perilaku prokrastinasi akademik yang tinggi merupakan awal dari timbulnya permasalahan. Apalagi, jika pekerjaan itu merupakan suatu kebaikan atau pekerjaan yang sangat penting.

Dalam hadis lain, Rasulullah SAW bersabda, yang artinya "Bersegeralah kamu sekalian melakukan amal-amal yang shalih, karena akan terjadi suatu bencana yang menyerupai malam yang gelap gulita, di mana ada seseorang pada waktu pagi ia beriman tetapi pada waktu sore ia kafir, pada waktu sore ia beriman tetapi pada waktu pagi ia kafir; ia rela menukar agamanya dengan satu kesenangan dunia." (HR Muslim). Dalam hadis ini dapat diambil suatu hikmah bahwa umat Islam sangat dianjurkan untuk bersegera melakukan suatu amal kebaikan atau pekerjaan-pekerjaan yang bisa membawa manfaat bagi diri individu, serta dapat menjauhkan diri dari perilaku prokrastinasi akademik (perilaku menunda), karena dengan memiliki perilaku prokrastinasi akademik yang tinggi dapat membawa suatu kebiasaan-kebiasaan buruk bagi diri individu itu sendiri.

Berdasarkan penjelasan diatas dapat dipahami ada beberapa alasan yang menyebabkan dilarangnya menunda pekerjaan. Pertama, kita tidak dapat menjamin untuk hidup pada esok hari. Kedua, tidak ada jaminan esok kita masih diberi nikmat kesehatan, memiliki waktu luang seperti hari ini. Ketiga, menunda pekerjaan yang baik menyebabkan seseorang terbiasa melakukannya, sehingga kemudian menjadi suatu kebiasaan buruk yang sulit dihilangkan. Waktu berjalan sesuai dengan sunatullah. Detik menjadi menit, menit menjadi jam, dan jam menjadi hari, begitu seterusnya. Siang dan malam pun datang silih berganti. Allah SWT berfirman, "Dan Dialah yang 
menjadikan malam dan siang silih berganti bagi orang yang ingin mengambil pelajaran atau orang yang ingin bersyukur." (QS 25:62).

Perilaku prokrastinasi akademik ( menunda pekerjaan) ini merupakan perilaku tercela karena ia menyia-nyiakan nikmat waktu yang telah diberikan oleh sang pemilik waktu Allah SWT, seperti dalam HR Bukhari, Rassulullah bersabda: "dua nikmat yang sering dilupakan oleh manusia adalah kesehatan dan waktu luang".

\section{SIMPULAN}

Perilaku prokrastinasi akademik merupakan hal yang sangat perlu dihindari atau dijauhkan dari dalam diri umat Islam, hal ini disebabkan karena perilaku prokrastinasi akademik dapat membawa banyak permasalahan baginya dikemudian hari. Terbukti dengan banyaknya dalil-dalil hadits dan Al-qur'an yang melarang dan bahkan mencela manusia yang melakukan perilaku prokrastinasi akademik (menunda-nunda pekerjaan).

\section{REFERENSI}

Ferrari, J. (1995). Self Handicapping by Procrastinator: Protecting Self-Esteem, Social Esteem, or Both?. Journal Research in Personality, Vol.25. No.2.

Ghufron.M.N dan Risnawati R.S (2010) Teori-Teori Psikologi, Ar-Ruzz Media, Jakarta.

Ghufron M.N (2003) Hubungan Kontrol diri dan Persepsi Remaja terbadap Penerapan Disiplin Orang Tua dengan Prokrastinasi Akademik, Tesis, Yogyakarta, Fakultas Psikologi, UGM.

Mustami'ah (2010) Hubungan antara Persepsi mahasiswa terhadap metode pengajaran dosen dengan kecenderungan prokrastinasi akademik pada mahasiswa fakultas pskologi universitas hantuah Surabaya, Jurnal Insan Media, Vol 12 No 2

Muyana (2018) Prokrastinasi akademik dikalangan mahasiswa program studi Bimbingan dan konseling, Jurnal Bimbingan dan Konseling,Vol.8 No.1

Rizvi. A (1998) Pusat Kendali dan Efikasi Diri sebagai Prediktor terhadap Prokrastinasi Akademik Mahasiswa, Skripsi (jogjakarta, Fakultas Psikologi, UGM)

Soetjipto H.P, dkk (1997) Pusat Kendali dan efikasi Diri sebagai Prediktor terbadap Prokrastinasi Akademik Mahasiswa, Jurnal Psikologika.

Solomon dan Rothblum (1984) Academic Procrastination: Frequency and cognitive-behavioral- correlate. Journal of counseling psychology, Vol.31 No.4 503-509

Steel, P. (2007). The Nature Of Procrastination: A Meta-Analytic and Theoritical Review Of Quintessential Self- Regulatory Failure. Psychological Bulletin Copyright 2007 by the American Psychological Association, Vol. 133, No. 1, 65-94. 
Sujadi, E. (2018). Perbedaan Locus of Control ditinjau dari Etnis. Jurnal Bimbingan Dan Konseling Terapan, 2(2), 128-138. https://doi.org/10.30598/jbkt.v2i2.371

Sujadi, Eko. (2015). Konseling Pancawaskita untuk Membentuk Problem Focused Coping. Jurnal Konseling Dan Pendidikan, 3(1), 14-24. https://doi.org/https://doi.org/10.29210/112100

Sujadi, Eko. (2017). Penerapan Pendidikan Karakter Cerdas Format Kelompok Untuk Meningkatkan Nilai Kejujuran Mahasiswa Bimbingan Konseling Islam (BKI) Institut Agama Islam Negeri (IAIN) Kerinci. Tarbawi : Jurnal Ilmu Pendidikan, 13(1), 97-108.

Sujadi, Eko. (2018). Kode Etik Profesi Konseling Serta Permasalahan dalam Penerapannya. Tarbawi : Jurnal Ilmu Pendidikan, 14(2), 69-77. https://doi.org/10.32939/tarbawi.v14i2.298

Sujadi, Eko. (2019). Penerapan Play Therapy dengan Menggunakan Permainan Tradisional untuk Meningkatkan Keterampilan Sosio Emosional. Jurnal Bimbingan Dan Konseling Terapan, 3(1), 14-24. https://doi.org/http://dx.doi.org/10.30598/jbkt.v3i1.892 